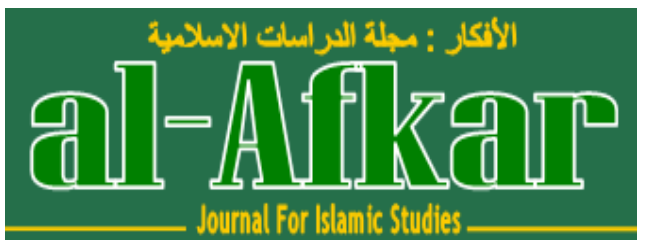

Vol. 2, No. 2, July 2019

P-ISSN : 2614-4883; E-ISSN : 2614-4905

https://al-afkar.com/index.php/Afkar_Journal/issue/view/4

DOI: https://doi.org/10.31943/afkar_journal.v4i1.50

\title{
STUDI KOMPARATIF TENTANG WAKAF UANG MENURUT IMAM MAWARDI DAN IBN NAJIM AI-MISHRI
}

\section{Dede Suryana}

Fakultas Agama Islam Universitas Ibnu Khaldun Bogor

E-mail:dedesuryana503@gmail.com

\section{Sutrisna}

Fakultas Agama Islam Universitas Ibnu Khaldun Bogor

E-mail: sutisna@fai.uika-bogor.ac.id

\section{Mukhtar}

Fakultas Agama Islam Universitas Ibnu Khaldun Bogor

E-mail:mukhtar@fai.uika-bogor.ac.id

\begin{tabular}{|c|c|c|}
\hline Received & Revised & Accepted \\
\hline 3 Juny 2019 & 20 Juny 2019 & 1 July 2019 \\
\hline
\end{tabular}

\section{THE COMPARATIVE STUDY ABOUT MONEY WAKAF ACCORDING TO IMAM MAWARDI AND IBNU NAJIM AL-MISHRI}

\begin{abstract}
Abstrak:
Wakaf is one of the philanthropic institutions of Islam that can reliably support the social justice agenda, especially among the Islamic community. He is one way of using the treasures recommended by Allah SWT and Prophet Muhammad SAW, wakaf has been implemented since the time of the current Rosuluh with a wider form that is not only waqf in the form of non-asset but also wakaf in the form of money that is commonly known as waqf money / cash waqf. Therefore, the writer tries to eradicate the law in conveying the money of obedient scholars syafi'iyah and ulama hanafiah thus giving more understand to us about law and benefit of cash waqf.
\end{abstract}

Keywords: comparative studies, money wakaf, the thinking of Imam Mawardi and Ibn Najim Al-Mishri 


\begin{abstract}
Abstrak
Wakaf adalah salah satu lembaga filantropis Islam yang dapat dipercaya mendukung agenda keadilan sosial, terutama di kalangan masyarakat Islam. Ia adalah salah satu cara menggunakan harta yang direkomendasikan oleh Allah SWT dan Nabi Muhammad SAW, wakaf telah diterapkan sejak masa Rosuluh saat ini dengan bentuk yang lebih luas yaitu tidak hanya wakaf dalam bentuk non-aset tetapi juga wakaf dalam bentuk dari uang yang biasa dikenal dengan uang wakaf / wakaf tunai. Oleh karena itu, penulis mencoba untuk memberantas hukum dalam menyampaikan uang para ulama syafi'iyah dan ulama hanafiah sehingga memberikan lebih banyak pemahaman kepada kita tentang hukum dan manfaat wakaf tunai.
\end{abstract}

Kata kunci: Studi komparatif, wakaf uang, pemikiran Imam Mawardi dan pemikiran Ibn Najim Al-Mishri

\title{
Pendahuluan
}

Wakaf merupakan salah satu institusi filantropi Islam yang bisa diandalkan menunjang agenda keadilan sosial khususnya di kalangan masyarakat Islam. Ia merupakan salah satu cara penggunaan harta yang dianjurkan oleh Allah SWT dan Nabi Muhammad SAW, wakaf telah dilaksanakan sejak zaman Rosul hingga saat ini dengan bentuk yang lebih luas yaitu tidak hanya wakaf dalam bentuk asset nonkas tapi juga wakaf dalam bentuk uang tuani yang biasa dikenal dengan wakaf uang/wakaf tunai. Wakaf tbertujuan untuk kemaslahatan manusia dengan mendekatkan diri kepada Allah, dan untuk memperoleh pahala yang berkesinambungan dari pemanfaatan harta yang diwakafkan, yang akan terus mengalir walaupun pewakaf sudah meninggal dunia. ${ }^{1}$

Adapun Pada satu sisi wakaf berfungsi sebagai sarana hablum minallah karena wakaf pun termasuk ibadah yang langsung kepada Allah, dan di sisi lain wakaf pun menjadi sarana ibadah hablum minannas yang terkait dengan ibadah antar sesama manusia yang hasil dan maanfaatnya dapat dirasakan orang banyak dan dapat bertahan secara lama tanpa adanya gangguan dari siapa pun.

Padahal jika kita amati dan kita telaah pengertian wakaf itu artinya luas tidak hanya sekedar menahan saja, tetapi dari pengertian menahan ini wakaf bisa dipergunakan secara luas, efektif dan dirasakan orang lebih banyak lagi, di era zaman sekarang yang semakin berkembang orang kebanyankan mengetahui benda yang dapat diwakafkan hanya seperti benda tak bergerak yaitu: tanah, bangunan/rumah, sarana tempat ibadah, tempat pendidikan dan benda-benda tidak bergerak lainnya. Padahal pada perkembanganya benda/harta yang dapat diwakafkan itu banyak.

\footnotetext{
${ }^{1}$ Wasilah Sri Nurhayati, “Akuntansi Syariah Di Indonesia," Salemba Empat. Jakarta, 2013.
} 
Wakaf juga merupakan salah satu institusi filantropi Islam yang bisa diandalkan menunjang agenda keadilan sosial khususnya di kalangan masyarakat Islam. Hal ini telah dibuktikan dalam sejarah filantropi Islamabad pertengahan, yang jejak keagungannya masih dapat disaksikan di negeri-negeri Muslim, seperti Turki dan Mesir. Wakaf pada masa itu bukan hanya didirikan untuk santunan fakir dan miskin atau untuk kegiatan keagamaan, melainkan hadir untuk membangun dan memelihara fasilitas umum non-keagamaan. Misalnya, ada wakaf untuk jembatan, wakaf untuk menara kontrol lalu lintas kapal laut, wakaf untuk irigasi pertanian, wakaf untuk pemandian dan air minum umum, serta wakaf untuk taman perkotaan. Bahkan ada wakaf untuk memberi makan burung di musim dingin.

Secara umum orang lebih mengenal istilah wakaf hanya untuk orang muslim (orang yang beragama Islam), keberadaan wakaf di Indonesia adalah digunakan untuk masjid, musholla, sekolah, rumah, jariyah, tanah pertanian, yatim piatu. Pemanfaatan tersebut dilihat dari segi sosial khususnya untuk kepentingan peribadatan memang efektif, tetapi dampaknya kurang berpengaruh positif dalam kehidupan ekonomi masyarakat.

Apabila peruntukan wakaf hanya terbatas pada hal-hal di atas tanpa diimbangi dengan wakaf yang dikelola secara produktif, maka kesejahteraan sosial ekonomi masyarakat yang diharapkan dari lembaga wakat tidak akan terealisasi secara optimal di masa pertumbuhan ekonomi di Indonesia yang cukup memprihatinkan saat ini, sesungguhnya peranan wakaf di samping instrumen-instrumen ekonomi Islam lainnya seperti zakat, infaq, sedekahdan lain-lain belum dapat dirasakan manfaatnya untuk meningkatkan taraf hidup masyarakat khususnya di bidang ekonomi.

Padahal permasalahan terkait wakaf berkembang dengan pesat salah satu alternatifnya adalah dengan adanya wakaf tunai (cash wash), meski wakaf pada mulanya hanya keinginan seseorang yang ingin berbuat baik dengan menggunakan kekayaannya yang dikelola dengan system yang tidak pasti maka setelah dirasa maanfaat wakaf tersebut maka timbullah keinginan untuk perwakafan dengan cara yang baik.

Namun dimasyarakat kadang kala wakaf diartikan dengan sesuatu hal yang bersifat hibah ataupun sedekah padahal antara wakaf ,sedekah, hibah itu merupakan sesuatu yang berbeda, seperti kita ketahui bersama bahwa yang mewakafkan biasanya hanya orang-orang yang mempunya kecukupan harta atau orang yang mempunyai harta berlebih lalu mempunyai niat baik untuk mendermakan sebagian harta yang dimiliki untuk diwakaf untuk umum dengan tujuan dapat dirasa maanfaatnya dari adanya wakaf tersebut.

\section{Landasan Teori}

\section{Pengertian Wakaf}




\section{Dede Suryana, Sutrisna, \& Mukhtar}

Studi Komparative tentang Wakaf Uang......

Kata "wakaf" atau waqf" berasal dari bahasa arab "waqaf". Asal kata "waqafa" berarti "menahan" atau "berhenti" atau "diam di tempat" atau tetap berdiri". "Kata waqafa-yaqifu-waqfan" sama artinya dengan "Habasa-yahbisu-Tahbisan" yang artinya menahan. ${ }^{2}$

Sedangkan dalam pengertian istilah, ulama berbeda redaksi dalam merumuskan dan memberikan beberapa pengertian, sebagaimana tersebut di bawah ini:

a. Menurut Imam Syafi'iyyah:

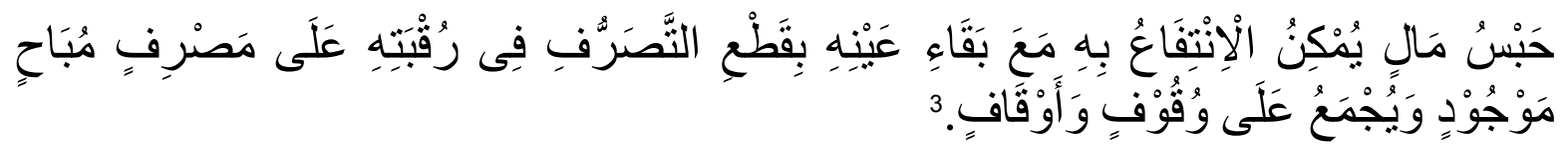

"Menahan harta yang diambil manfaatnya dengan tetap utuhnya barang, dan barang itu lepas dari penguasaan si wakif serta dimanfatkan pada suatu yang diperbolehkan oleh agama yang telah disepakati".

b. Menurut Imam Hanabilah:

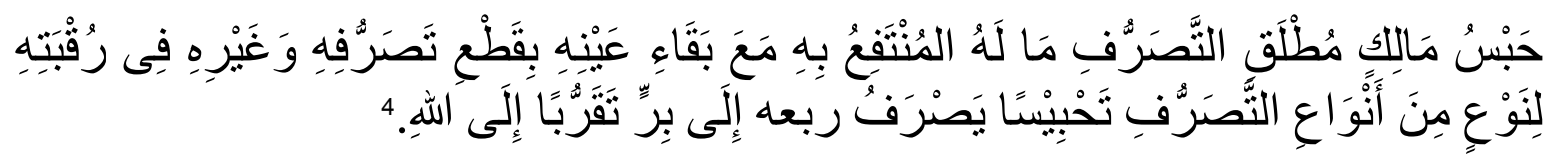

"Menahan kebebasan pemilik harta dalam membelanjakan hartanya yang bermanfaat dengan tetap utuhnya harta dan memutuskan semua hak penguasaan terhadap harta dipergunakan pada suatu kebaikan untuk mendekatkan diri kepada Allah SWT".

Dari beberapa istilah di atas dapat diambil kesimpulan bahwa:

1. Harta yang diwakafkan itu keluar atau terputus dari hak milik orang yang mewakafkan dan menjadikan milik Allah SWT atau milik khalayak banyak, akan tetapi sebagaimana ulama berpendapat bahwa harta wakaf masih tetap menjadi milik orang yang mewakafkan, seperti menurut Imam Hanafiyah dan Imam Malikiyah yang berpendapat harta wakaf itu masih tetap di pihak si wakif yang diambil hanyalah manfaatnya saja, sedangkan pendapat lainnya menyatakan bahwa harta wakaf itu benarbenar sudah terputus dari pihak pemilikan orang yang mewakafkan. ${ }^{5}$

2. Dari harta wakaf yang disedekahkan hanya manfaatnya saja, sedangkan barangnya ('ainnya) harus tetap, dan bendanya bersifat kekal zatnya, tidak akan habis dipakai.

\footnotetext{
${ }^{2}$ Wahba az-Zuhailī, Al-Fiqh Al-Islāmī Wa-Adillatuhu: Aš-Šāmil Lil-Adilla Aš-Šar'īya Wa-'I-Ārā'al-Madhabīya Wa-Ahamm an-Naẓarīyāt Al-Fiqhīya Wa-Taḥqīq Al-Ahādīt an-Nabawīya Wa-Ta. Hrīğihā Mulhaqqan Bihi Fahrasa Alifbā'iya Šāmila Lil-Maựū'āt Wa-'I-Masā'il Al-Fiqhīya. Tatimm (Dār al-fikr, 1984).

${ }^{3}$ Asy-Syarbaini Al-Khatib, “Mughni Al-Muhtaj,” Juz II, Mesir: Al-Baby Al-Halaby Wa Auladuhu, 1958.

${ }^{4}$ az-Zuhailī, Al-Fiqh Al-Islāmī Wa-Adillatuhu: Aš-Šāmil Lil-Adilla Aš-Šarīya Wa-'I-Ārā'al-Mad̆habìya WaAhamm an-Naẓarīyāt Al-Fiqhīya Wa-Tahqīiq Al-Ahādīt an-Nabawīya Wa-Ta. Hrīğihā Mulhaqqan Bihi Fahrasa Alifbā'iya Šāmila Lil-Maudūūāt Wa-'l-Masā'il Al-Fiqhīya. Tatimm.

${ }^{5}$ Faishal Haq and H A Saiful Anam, Hukum Wakaf Dan Perwakafan Di Indonesia (Garoeda Buana Indah, 1993).
} 
3. Boleh mewakafkan manfaat suatu benda, atau manfaat dari benda tersebut, untuk kepentingan umum sesuai dengan ajaran Islam ${ }^{6}$.

Maka dari semua pengertian wakaf di atas dapat disimpulkan bahwa pengertian wakaf dalam Syariat Islam jika dilihat dari perbuatan orang yang mewakafkan. Wakaf merupakan suatu perbuatan hukum artinya bahwa perbuatan mewakafkan suatu benda menimbulkan suatu akibat hukum. Akibat hukum yang dimaksud adalah bahwa benda wakaf itu memiliki status tersendiri di dalam lalu lintas hukum. Artinya sudah dipisahkan dari kepemilikan si wakif, sedangkan unsur kekal memberikan arti bahwa benda yang diwakafkan tidak dapat diperjual belikan atau dialihkan haknya.

\section{Dasar Hukum Wakaf}

Dasar hukum wakaf sebagai lembaga yang diatur dalam ajaran Islam tidak dijumpai secara tersurat dalam al-Qur'an. Namun demikian, terdapat ayat-ayat yang mempertunjukan dan dapat dijadikan sebagai sumber hukum perwakafan. Ayat-ayat yang difahami berkaitan dengan wakaf, antara lain.

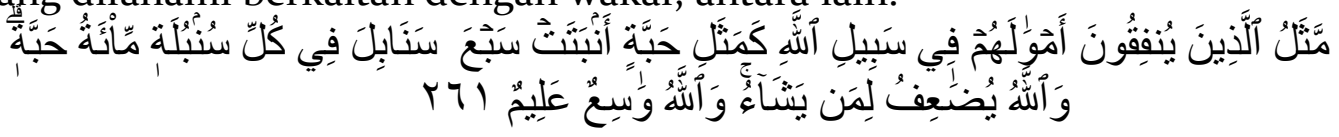

Artinya: Perumpamaan (nafkah yang dikeluarkan oleh) orang-orang yang menafkahkan hartanya di jalan Allah [Pengertian menafkahkan harta di jalan Allah meliputi belanja untuk kepentingan jihad, pembangunan perguruan, rumah sakit, usaha penyelidikan ilmiah dan lain-lain] adalah serupa dengan sebutir benih yang menumbuhkan tujuh butir, pada tiap-tiap butir seratus biji. Allah melipat gandakan (ganjaran) bagi siapa yang dia kehendaki. dan Allah Maha luas (karunia-Nya) lagi Maha Mengetahui. (QS. al-Baqarah: 261).

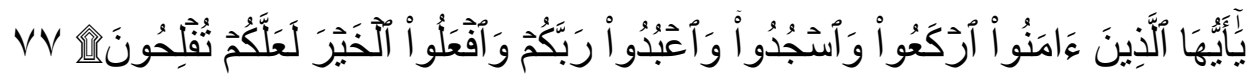

Artinya: Hai orang-orang yang beriman, ruku'lah kamu, sujudlah kamu, sembahlah Tuhanmu dan perbuatlah kebajikan, supaya kamu mendapat kemenangan. (QS. alHajj/22: 77).

Jadi berdasarkan ayat tersebut, penulis memberikan pengertian bahwasanya setiap amal kebaikan yang dilakukan oleh seseorang dengan semata-mata karena mengharapkan keridhoan Allah SWT maka akan mendapatkan balasan yang berlipat ganda. Karena Allah SWT menjanjikan kepada orang-orang yang menafkahkan hartanya akan dilipat gandakan pahalanya menjadi tujuh ratus kali lipat.

Wakaf yang pertama kali dilakukan dalam Islam adalah wakaf yang dilakukan oleh sahabat Umar bin Khatab ra. Yang diterangkan dalam hadits sebagai berikut:

\footnotetext{
${ }^{6}$ Ugin Lugina, "Pengembangan Ekonomi Pondok Pesantren Di Jawa Barat," Risâlah, Jurnal Pendidikan Dan Studi Islam 4, no. 1 (2017): 53-64.
} 


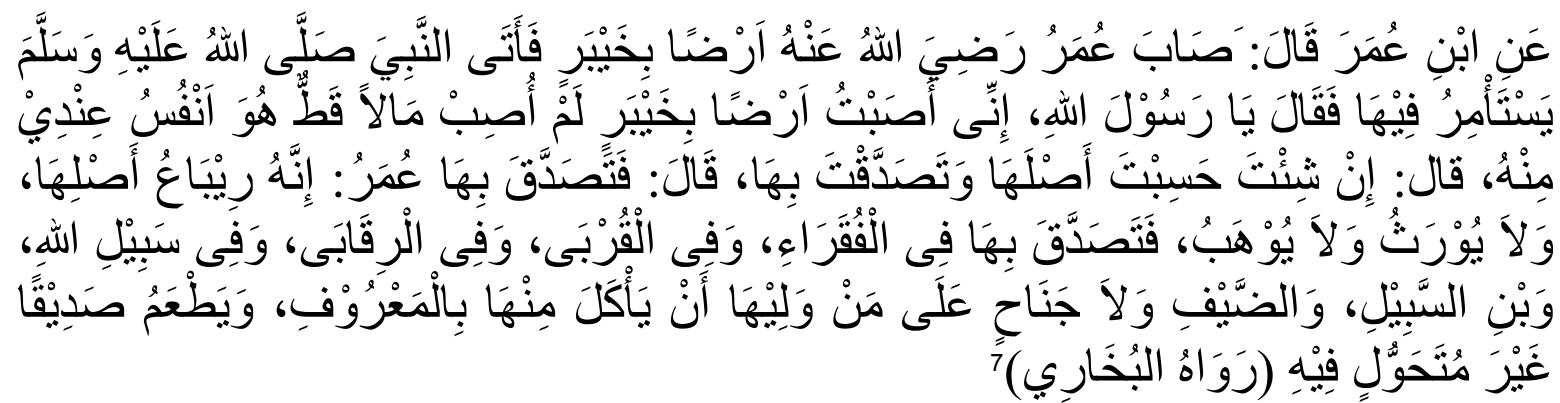

Artinya: "Dari Ibnu Umar ra, berkata: Umar ra, telah menguasai sebidang tanah di Khaibar lalu ia datang kepada Rasulallah SAW untuk meminta fatwanya sehubungan tanah tersebut, Ia berkata: "Ya Rasulullah SAW, aku telah memperoleh sebidang tanah di kaibar, yang aku tidak menyenanginya seperti padanya, apa yang engkau perintahkan kepadaku dengannya. "Maka Rasulullah SAW bersabda: "Jika kamu Menginginkan, tanah aslinya, shadaqohkan hasilnya”. Kemudian Umar bersodaqah, tanah tersebut tidak bisa dijual, dihibahkan, dan diwariskan. Umar menyedekahkan kepada orang-orang fakir, kaum kerabat, budak belian, sabilillah, Ibnu Sabil dan tamu. Dan tidak mengapa atau tidak dilarang bagi yang menguasai tanah wakaf itu (pengurusnya) atau makan dengan tidak bermaksud memperkaya diri". (HR. Bukhari).

Hadits ini memberi pengertian bahwa barang yang telah diwakafkan tidak boleh dijual, dihadiahkan dan diwariskan. Hasilnya dapat disediakan kepada fakir miskin, sanak kerabat, untuk memerdekakan budak, sabilillah, Ibnu Sabil dan tamu. Kemudian yang mengurus harta wakaf tidak dilarang untuk mengambil (makan) dari hasil tersebut dengan cara yang baik dan memberi makanan kepada sahabatnya dengan baik 8 .

Menurut Imam al-Kahlani dalam Subul al-Salam, dalam konteks haditshadits yang disebutkan di atas para ulama mendefinisikan al-shadaqoh jariyah sama dengan wakaf. Dan hal inilah yang menyebabkan hadits-hadits tersebut terdapat atau diletakkan pada bab wakaf. ${ }^{9}$

\footnotetext{
${ }^{7}$ Muhammad bin Ismail Abu Abdillah and Muhammad bin Ismail, "Al-Bukhari Al-Jafi, Al-Jami Al-Shahih AlMuhtasar," Jilid I, Beirut: Dar Ibn Katsir, 1987.

${ }^{8}$ Sasa Sunarsa, "TAFSIR THEORY; STUDY ON AL-QURAN METHODS AND RECORDS.(TEORI TAFSIR; KAJIAN TENTANG METODE DAN CORAK TAFSIR AL-QURAN)," Al-Afkar, Journal For Islamic Studies 3, no. 1 (2019): 247-59.

${ }^{9}$ Imam Ash-Shan'ani and Imam Muhammad bin Ismail al Kahlani, "Subulus Salam Juz III," Bandung: Dahlan, 1995.
} 


\section{Rukun Dan Syarat Wakaf}

\section{Rukun Wakaf}

Dalam wakaf ada bebrapa rukun yang harus dipenuhi sebagai berikut:

1. Orang Yang Berwakaf (Wakif)

Pada hakikatnya amalan wakaf adalah tindakan tabarru' (mendermakan harta benda), karena itu syarat seorang wakif adalah cakap melakukan tindakan tabarru'. Artinya, sehat akalnya, dalam keadaan sadar, tidak dalam keadaan terpaksa/dipaksa, dan telah mencapai umur baligh ${ }^{10}$ dan wakif juga benar-benar pemilik harta yang diwakafkan. ${ }^{11}$ Oleh karena itu, orang gila, anak-anak, dan orang yang terpaksa dan dipaksa tidak sah. Dan orang yang berwakaf disyaratkan sebagai pemilik sah dari harta yang diwakafkan.

a. Harta Yang Diwakafkan (Mauquf) yaitu:

Dalam mewakafkan harta, agar dianggap sah, maka harus memenuhi syarat

1). Barang yang bisa diambil manfaatnya dengan tetap kekal materinya, tidaklah diisyaratkan harta yang diwakafkan ini bisa diambil langsung manfaatnya seketika itu juga, karena itu mewakafkan tanah yang tandus untuk diperbaiki baru kemudian ditanami hukumnya sah.

2). Benda yang diwakafkan itu mesti milik sah dari pihak yang berwakaf, harus merupakan benda milik yang terbebas dari segala pembebanan, ikatan, sitaan, dan sengketa. Sebab wakaf adalah suatu tindakan yang menyebabkan terbebasnya suatu kepemilikan menjadi harta wakaf.

3). Bukan barang haram dan najis. ${ }^{12}$

b. Mauquf 'Alaih (Tujuan Wakaf)

Dalam mewakafkan suatu harta benda harus mempunyai tujuan yang jelas. Apakah seseorang mewakafkan untuk keperluan atau menolong keluarganya sendiri atau untuk kepentingan umum. Yang jelas tujuan wakaf adalah untuk kebaikan dan mencari keridhoan Allah SWT. Untuk lebih jelasnya bahwa tujuan wakaf adalah:

1) Untuk mencari keridhoan Allah SWT. Termasuk di dalamnya usaha untuk menegakkan agama Islam, seperti membangun tempat ibadah (Masjid, Musholla, Pondok Pesantren, Asrama dan lain sebagainya), kegiatan dakwah atau membangun sarana pendidikan berbasis Islam. Oleh karena itu, tidak boleh kita mewakafkan harta benda untuk keperluan maksiat.

2) Untuk kepentingan masyarakat, seperti membantu fakir miskin, orang-orang terlantar, kerabat, mendirikan sekolah, asrama yatim piatu dan sebagainya. ${ }^{13}$ Karena tujuan wakaf untuk mencari ridho Allah SWT, maka tidak boleh

\footnotetext{
${ }^{10}$ Abu Yahya Zakariya Al-Anshary, "Fath Al-Wahhab" (Juz, n.d.).

${ }^{11}$ Mohammad Daud Ali, Sistem Ekonomi Islam: Zakat Dan Wakaf (Penerbit Universitas Indonesia, 1988).

${ }^{12}$ Adijani Al Alabij, Perwakafan Tanah Di Indonesia Dalam Teori Dan Praktek (RajaGrafindo Persada, 1989).

${ }^{13}$ Ahmad Rofiq, Hukum Islam Di Indonesia (RajaGrafindo Persada, 1995).
} 
bertentangan dengan nilai-nilai ibadah, tujuan wakaf harus dapat dimasukkan ke dalam kategori ibadah pada umumnya, sekurang-kurangnya merupakan hal yang mudah menurut ukuran (kaidah) Hukum Islam. Kalau tujuan wakaf itu untuk kepentingan umum, maka harus ada badan yang mengurusnya, pengurus harta wakaf itu disebut nadzir, dapat berupa perorangan atau badan hukum (di Indonesia).

c. Shighat Wakaf atau Ikrar Wakaf

Pernyataan wakif yang merupakan tanda penyerahan barang atau benda yang diwakafkan itu, dapat dilakukan dengan lisan atau tulisan. Pernyataan wakif merupakan ijab, maka perwakafan telah terjadi. Sedangkan perkataan qabul dari mauquf alaih, yakni orang-orang yang berhak menikmati hasil wakaf. Menurut sebagian ulama berpendapat perlu ada qabul kalau penerimaan wakaf adalah pihak tertentu, tetapi kalau wakaf itu untuk umum, maka tidak harus ada qabul. ${ }^{14}$

\section{Syarat-syarat Wakaf}

Untuk sahnya amal wakaf, diperlukan beberapa syarat umum yang harus diperhatikan dalam melaksanakan wakaf, di antaranya adalah:

a). Tujuan wakaf tidak boleh bertentangan dengan kepentingan agama Islam. Misalnya mewakafkan tanah untuk dijadikan jalan umum yang akan dilakukan tanah untuk dijadikan jalan umum yang akan dilalui oleh orang Islam dan orang non Islam itu tidak apa-apa.

b). Perwakafan benda itu tidak dibatasi untuk jangka waktu tertentu saja, tetapi untuk selama-lamanya. Jadi, kalau orang yang mewakafkan itu membatasi waktunya untuk jangka waktu tertentu, misalnya mengatakan: "Saya mewakafkan barang ini untuk waktu sepuluh tahun, "atau" bila saya membutuhkannya, "atau" bila anak saya membutuhkannya, "dan redaksiredaksi seperti itu, maka apa yang akan dilakukan itu menyebabkan wakaf tersebut batal. ${ }^{15}$

c) Harus segera dilaksanakan setelah ikrar wakaf dinyatakan oleh wakif tanpa menguntungkan pelaksanaannya pada suatu peristiwa yang akan terjadi di masa yang akan datang.

d) Wakaf mesti dilakukan secara tunai dan tidak ada khiyar, karena wakaf berarti memindahkan milik waktu itu juga. ${ }^{16}$

e) Hendaklah disebutkan dengan jelas kepada siapa wakaf itu ditunjukan. Dengan demikian, bila seorang mewakafkan tanah tanpa menyebutkan tujuan sama sekali dipandang tidak sah. Meskipun demikian bila wakif menyerahkan wakafnya kepada suatu hukum, dapat dipandang sebagai wakaf.

\section{Macam-macam Wakaf}

\footnotetext{
14. Adi jani al-Alabij, Perwakafan Tanah di Indonesia dalam teori dan praktek, h.35

${ }^{15}$. Muhamad Jawad Nughiyah, Fiqih Lima Mazhab, Jakarta: Lentera, 2005, cet. 13, h.636

16. Suparman Usman, Hukum Perwakafan di Indonesia, Jakarta: Darul Ulum, 1994, Cet. Ke-1, h. 33
} 
a. Wakaf Ahli

Wakaf ahli adalah wakaf yang khusus ditunjukan kepada orang-orang tertentu, satu orang atau lebih dari satu orang, baik keluarga si wakif atau bukan. Wakaf seperti ini juga disebut dengan wakaf Dzurri.

Apabila seseorang mewakafkan sebagian tanah kepada anaknya, lalu kepada cucunya, wakafnya sah dan yang berhak mengambil manfaatnya adalah mereka yang ditunjukan dalam pernyataan wakaf tersebut. Sebagaimana dikatakan oleh Muhamad Daud Ali bahwa wakaf ahli atau Dzurri yang artinya: "Wakaf yang khusus yang dipertanggungkan kepada seseorang tertentu, seorang atau lebih baik keluarga si wakif atau bukan". ${ }^{17}$

b. Wakaf khairi

wakaf khairi adalah wakaf yang secara tegas untuk kepentingan agama (keagamaan) atau kemasyarakatan seperti wakaf yang diserahkan untuk keperluan pembangunan masjid, pesantren, sekolah, rumah sakit, panti asuhan dan lain sebagainya. Dalam hadits Rasulallah SAW:

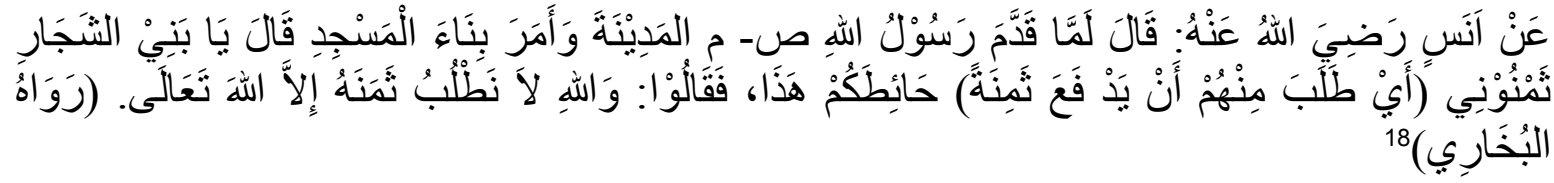

Artinya: "Dari Anas ra. ia berkata: ketika Rasulallah SAW tiba di kota Madinah beliau memerintahkan untuk membuat masjid, seraya berkata: "Hai Bani Najjar! Berikanlah harga dari kebun-kebun mu ini, mereka menjawab. "Demi Allah kami tidak ingin meminta harga kebun-kebun ini (dibeli), kecuali kami serahkan kepada Allah SWT.

Hadits ini memberi pengertian bahwa Wakaf khairi adalah wakaf yang sangat dianjurkan dalam Islam, sebab lebih banyak manfaatnya dari pada wakaf ahli, karena hasilnya dapat dinikmati oleh khalayak ramai dan salah satu sarana yang dapat menunjang kesejahteraan masyarakat, baik dalam bidang ekonomi, sosial, pendidikan dan keagamaan. Wakaf ini tidak terbatas pada satu orang atau kelompok tertentu saja, tetapi manfaatnya untuk umum, dan inilah yang paling sesuai dengan tujuan perwakafan.

Dalam wakaf khairi, si wakif dapat juga mengambil manfaatnya dari harta yang diwakafkan, seperti mewakafkan masjid maka si wakif boleh saja berad di masjid, atau mewakafkan sumur, maka si wakif boleh saja mengambil airnya.

\footnotetext{
${ }^{17}$.Ibid. h.89

${ }^{18}$. Ahmad bin Ali bin Hajar al-Asqalani, fathul Bari bi Syarhi al-Bukhari, Beirut: Dar al-Fikr, 1996, Juz 6 h. 63-64
} 


\section{Pengertian Wakaf Uang}

Munculnya pemikiran wakaf uang/tunai yang dipelopori oleh Prof. Dr. M.A. Mannan, seorang ekonomi yang berasal dari Bangladesh pada dekade ini merupakan momen yang sangat tepat untuk mengembangkan instrumen wakaf untuk membangun kesejahteraan umat. ${ }^{19}$

Menurut kamus istilah Ekonomi , Keuangan dan Bisnis Syariah wakaf uang adalah wakaf yang berbentuk uang tunai (cash waqf) adapun yang termasuk dalam pengertian uang adalah surat-surat berharga. Wakaf uang hanya boleh disalurkan dan digunakan untuk hal-hal yang dibolehkan secara syar'i , wakaf uang harus dijamin kelestarianya, tidak boleh dijual, dihibahkan maupun di wariskan. ${ }^{20}$

Sesuai dengan keputusan fatwa Majelis Ulama Indonesia (MUI) tertanggal 26 April 2002 diterangkan bahwa yang dimaksud dengan wakaf uang adalah wakaf yang dilakukan seseorang, kelompok orang, lembaga atau badan hukum dala bentuk tunai. Dalam pengertian tersebut, yang dimaksud dengan uang adalah surat-surat berharga.

Wakaf uang (cash waqf) yang merupakan inovasi dalam keuanngan public islam (Islamic society finance), karena jarang ditemukan pada fikih klasik. Wakaf tunai membuka peluang yang unik bagi penciptaan investasi di bidang keagamaan, pendidikan, dan pelayanan sosial, karena lebih fleksibe ldalam penggunaan dan pengelolaanya. Pendapatan yang diperoleh dari pengelolan wakaf tunai tersebut juga dapat dibelanjakan untuk berbagai tujuan yang berbeda seperti pemeliharaan hartaharta wakaf itu sendiri. ${ }^{21}$

\section{Rukun dan Syarat Wakaf Uang}

Pada dasarnya rukun dan syarat wakaf uang adalah sama dengan rukun dan syarat wakaf tanah. Adapun rukun wakaf uang yaitu: ada orang yang berwakaf (Al- Wakif), ada harta yang diwakafkan (Al-Mauquf), ada tempat ke mana diwakafkan harta itu/tujuan wakaf (Al-Mauquf „alaih), dan ada akad/pernyataan wakaf (Sighat). ${ }^{32}$

Unsur-unsur wakaf tersebut harus memenuhi syaratnya masing-masing sebagaimana pada wakaf tanah. Sedangkan yang menjadi syarat umum sahnya wakaf uang adalah sebagai berikut:33 (a) Wakaf harus kekal (abadi) dan terus menerus; (b) Wakaf harus dilakukan secara tunai, tanpa digantungkan pada terjadinya suatu peristiwa di masa yang akan datang. Karena pernyataan wakaf berakibat pada lepasnya hak milik seketika setelah wakif menyatakan berwakaf. (c) Tujuan wakaf harus jelas, maksudnya adalah hendaknya wakaf itu disebutkan dengan terang dan jelas kepada siapa harta tersebut diwakafkan. (d) Wakaf merupakan hal yang harus dilaksanakan tanpa syarat boleh khiyar. Ini

\footnotetext{
${ }^{19}$ M.A. Mannan,Sertifikat Wakaf Tunai, Pancoran-Jaksel: CIBER - PKTTI-UI depok.

${ }^{20}$ Muhammad Sholahuddin.Kamus Itilah Ekonomi,Keuangan\& Bisnis Syariah. Jakarta : Pt Gramedia Pustaka. 2011.h.189

${ }^{21}$ Sri Nurhayati. Akuntansi Syariah di Indonesia-Wasilah. Jakarta: SalembaEmpat. 2013.h. 337
} 
artinya tidak boleh membatalkan atau melangsungkan wakaf yang telah dinyatakan, sebab pernyataan wakaf telah berlaku tunai untuk selamanya.

\section{Pendapat Ulama Syafi'iyyah Dan Hanfiyyah Tentang Wakaf Uang}

\section{Pendapat Imam Mawardi (Ulama Syafi'iyyah) Tentang wakaf uang}

Penulis menjadikan Ulama Syafi'iyyah dana Hanafi sebagai batasan analisa. Dengan demikian, maka penulis bermaksud memaparkan bagaimana pendapat Ulama Syafi'iyyah dan Hanafi yang berkaitan dengan hukum mewakafkan uang.

Maka penulis memulai membahas tentang pendapat Ulama Syafi'iyyah, yang penulis maksud dengan Ulama Syafi'iyyah adalah terbatas pada Ulama Fikih Syafi'i pada kitab yang penulis jadikan bahan hukum primer yaitu kitab Al-Hawi Al-Kabir karya Imam Mawardi.

Dalam pandangan Ulama- Ulama Syafi'iyyah wakaf adalah penahanan harta yang dapat dimanfaatkan dengan menjaga keutuhan barang untuk digunakan dalam hal-hal yang dibolehkan, dan pewakaf tidak berhak dalam ikut serta pengelolaan hartanya. ${ }^{22}$ Dalam mazhab Syafi'iyah, masalah mawakafkan uang mereka memiliki dua pendapat yang paling benar (ashah) adalah hukum pelarangan wakaf dengan harta berbentuk dinar dan dirham (emas dan perak), baik dimanfaatkan untuk perhiasan maupun untuk digunakan meraup keuntungan. Begitu pula bunyi salah satu riwayat mazhab Hanabilah, hukum wakaf uang adalah dilarang. bahwa:

Dalam kitab Al Hawi Kabir karya AL-Mawardi, Al-Mawardi berpendapat

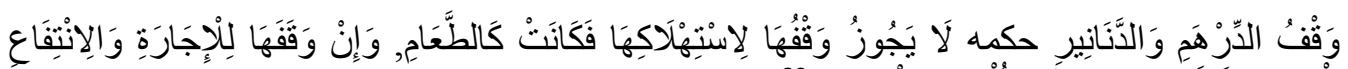

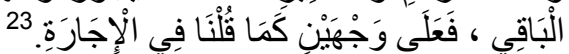

"wakaf dirham dan dinnar hukumnya tidak boleh dan istilah wakaf tersebut sama seperti makanan, maka wakaf tersebut bila disewakan dan dimanfaatkan, maka ada dua pendapat yang dijelaskan pada bab Ijarah"

Menurut AL-Mawardi mewakafkan dirham dan dinar (uang) hukumnya adalah tidak boleh karena uang akan habis apabila dipakai maka hukumnya seperti mewakafkan makanan yang akan habis apabila digunakan, adapun apabila mewakafkan uang untuk disewakan dan dimanfaatkan untuk wakaf dari sisa dari uang yang disewakan. Dan permasalahan mewakafkan uang untuk diwakafkan ada dua pendapat sebagaimana yang dijelaskan pada Bab Ijarah.

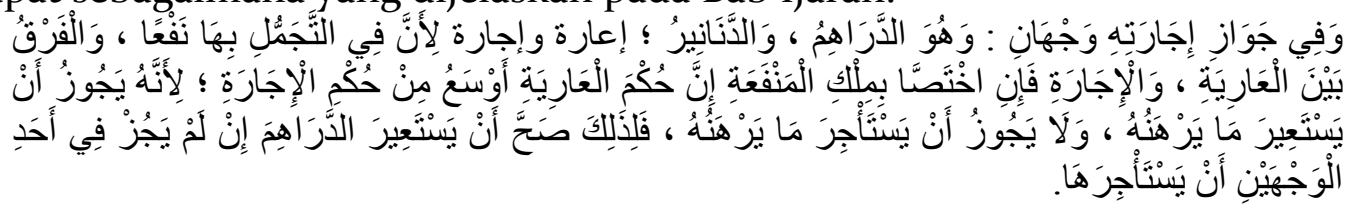

Di dalam kitab Al-Hawi Al-Kabir pada bab Ijarah Al-Mawardi menjelaskan tentang hukum menyewakan uang, dalam permasalahan ini uang bisa disewakan

\footnotetext{
${ }^{22}$ Al-Khathib al-Syarbiny, Mughni al-Muhtaj,Kairo, Darul Hadis, 2006, juz 3, h. 452.

${ }^{32}$ AL-Mawardi, Al-Hawi Al-Kabir, Juz VII,Beirut: Dar Al-Kutub Ilmiyah, 1994. h. 519
} 
dan dipinjamkan yang manfaatnya digunakan untuk perhiasan. Adapun dalam hukum uang untuk disewakan dan dipinjamkan memiliki perbedaan, untuk permasalahan uang yang dipinjamkan hukumnya lebih luas dari permasalahan uang yang disewakan.

Menurut Al-mawardi hukum meminjamkan uang untuk digadaikan hukumnya dibolehkan, sedangkan uang yang disewakan untuk digadaikan hukumnya tidak boleh.

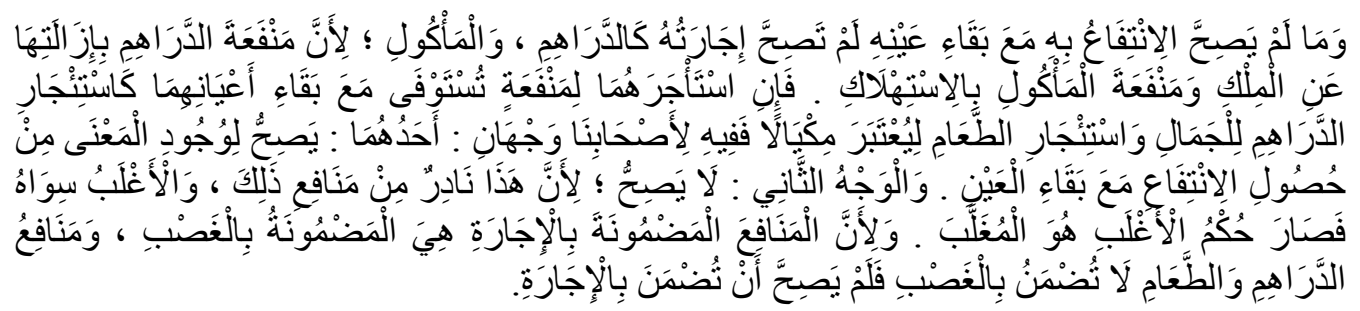

Dan tidak sah/benar digunakan untuk kemanfaatan hidup benda-benda mereka seperti sewa dirham untuk makanan dan penyewaan Jika tidak sah menggunakannya dengan mata yang sama, maka tidak sah untuk menyewanya seperti dirham dan sejenisnya, karena manfaat dirham adalah mengeluarkannya dari si pemilik harta dan untuk memberi manfaat bagi yang demikian itu. Jika dia menyewakannya untuk keuntungan yang dipenuhi dengan kelangsungan makanan untuk dianggap sebagai standar bagi pemilik kedua belah pihak: satu,sah wujud benda yang untuk digunakan untuk mendapat kemanfaatan dengan kekalnya benda tersebut. Aspek kedua adalah bahwa hal itu tidak sah/benar, karena ini jarang terjadi dari segi manfaatnya, dan mayoritas seperti itu Dan karena manfaat yang dijamin oleh Ijarah dijamin dengan memaksa, dan manfaat dirham dan makanan tidak menjamin dengan memaksa, maka tidak benar/sah menjamin Ijara. ${ }^{24}$

Al-Mawardi kembali menjelaskan mengenai hukum mewakafkan uang untuk disewakan, menurut Al-Mawardi uang tidak sah untuk dimanfaatkan untuk disewakan sebagaimana dalam permasalahan wakaf uang karena uang hanya bisa diambil manfaatnya dengan cara menghilangkannya dari kepemilikan sehingga uang tersebut habis. Menurut Al-Mawardi tentang kebolehan menyewakan uang ada dua pendapat diantara murid-murid Imam Syafi'i, Pertama, boleh karena ketika menyewakan uang terdapat sebab yang membolehkan yaitu bisa diambil manfaatnya dan uang tersebut tetap ada. Kedua, Tidak sah karena menyewakan uang untuk diambil manfaatnya adalah sesuatu yang jarang, maka sesuatu pekerjaan yang yang jarang tidak boleh dipakai karena menyalahi kebiasaan.

Dan Al-Mawardi juga memberikan penjelasan mengapa uang tidak boleh diwakafkan untuk dipergunakan disewakan, menurut Al-Mawardi uang yang diwakafkan dan digunakan untuk ijarah digantungkan kepada apabila uang tersebut dicuri atau ketika menjadi modal usaha mengalami kerugian maka tidak wajib mengganti maka hukum memwakafkan uang tidak sah.

${ }^{24}$ Ibid. Hal. 391 
Dari pendapat ini dapat kita ketahui bahwa apabila uang diwakafkan baik untuk dipergunakan untuk ijarah atau untuk dijadikan modal usaha (mudharabah) maka manfaatnya akan hilang apabila uang tersebut dicuri atau hilang, dan jika dijadikan modal usaha manfaat uang akan hilang apabila yang menjalankan usaha mengalami kerugian maka uang yang diwakafkan akan berkurang bahkan uang tersebut akan habis apabila kerugiannya besar, sedangkan kerugian harus ditanggung bersama, maka hukum mewafkan uang untuk dijadikan modal usaha (mudharabah) hukumnya tidak boleh karena uang tersebut akan habis apabila mengalami kerugian.

\section{Pendapat Ibn Najim Al-Mishri (Hanafiyyah) tentang Wakaf Uang}

Selain Ulama Syafi'iyyah penulis juga menjadikan Ulama Hanafi sebagai batasan pembahasan, selain itu yang penulis maksud dengan Ulama Hanafi yaitu terbatas pada Ulama Fikih mazhab Hanafi pada kitab yang penulis jadikan bahan primer, yaitu Al-Bahru Al-Raiq Sarh Kanju Al-Daqa’iq karya Ibn Najim Al-Mishri.

Berbeda dengan pendapat Al-Mawardi di dalam kitab al-Hawi Kabir yang menyatakan bahwa wakaf uang tidak sah, pendapat Ibn Najim Al-Mishri Al-Hanafi di dalam kitabnya Al-Bahru Al-Ra’iq Sarh Kanju Al-Daqa’iq menyebutkan bahwa mewakafkan uang hukumnya boleh berdasarkan pendapat Ashhab Zufar:

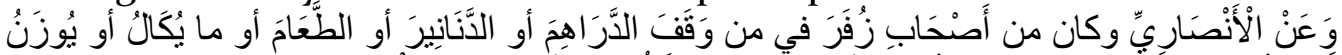

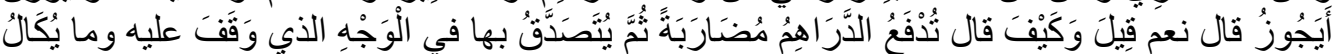

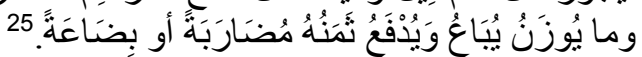

"Atas wewenang al-Ansari, yang termasuk di antara mereka yang telah mengeluarkan dalam menghentikan dirham, dinar, makanan, atau apa yang dianggap atau ditimbang, dan berkata: bagaimana memindahkan dan bagaimana dia mengatakan bahwa dia akan membayar dirham itu untuk spekulasi dan kemudian dia akan memberikannya kepadanya bahwa dia berdiri dan apa yang dijual dan dibayar."

Beliau menjelaskan bahwa hukum mewakafkan uang, makanan, benda yang ditimbang atau ditakar hukumnya boleh, dan beliau juga menjelaskana bagaimana cara mewakafkan uang yaitu dengan cara menjadikan uang tersebut sebagai modal usaha dan memberikan keuntungannya untuk wakaf yang ditunjuk oleh pewakaf, sedangkan untuk makanan atau barang yang ditimbang atau ditakar maka benda tersebut dijual lebih dahulu dan hasil penjualan tersebut dijadikan modal usaha.

Ibn Najim Al-Mishri Al-Hanafi di dalam kitabnya Al-Bahru Al-Ra’iq Sarh Kanju Al-Daqa'iq juga menjelaskan tentang sahnya wakaf uang:

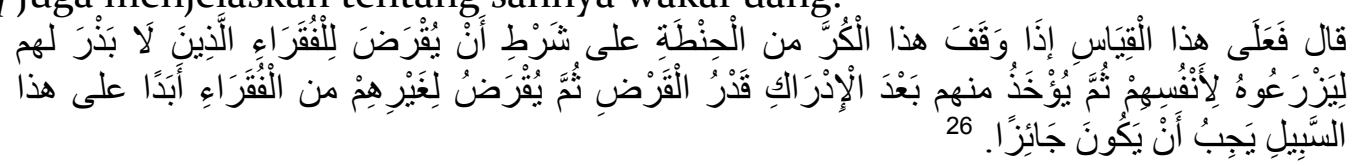

\footnotetext{
${ }^{25}$ Ibn Najim Al-Mishri Al-Hanafi, Al-Bahru Al-Ra'iq Sarh Kanju Al-Daqa’i, Juz V,Beirut: Dar Al Ma'rifah. h. 219
} 
"Dia mengatakan dalam ini dengan Qiyas, jika gandum ini berhenti dari gandum dengan syarat akan memberi pinjaman kepada orang miskin yang tidak menabur agar mereka menanamnya sendiri, maka akan diambil dari mereka setelah mendapati jumlah pinjaman dan kemudian memberi pinjaman kepada orang miskin lainnya di jalan ini, maka hal tersebut dibolehkan."

Maka permasalah ini menurut beliau berdasarkan Qiyas kepada permasalahan apabila mewakafkan satu takar biji gandum dengan syarat dijadikan pinjaman bagi orang miskin yang tidak suka membuang-buang harta dan biji gandum tersebut mereka tanam yang hasilnya untuk mereka, dan apabila yang menerima wakaf telah panen maka ${ }^{27}$ diambil kembali dengan ukuran yang sama dengan biji gandum yang diwakafkan, dan satu takar gandum tersebut diwakafkan kembali untuk fakir yang lain dan seterusnya, maka dengan cara seperti ini hukum mewakafkannya adalah boleh.

Setelah penulis memaparkan pendapat-pendapat Ulama Hanafi tentang hukum mewakafkan uang maka penulis dapat mengambil kesmpulan bahwa hukum mewakafkan uang menurut ulama Hanafi hukumnya boleh dengan cara menjadikan uang tersebut modal usaha dan keuntungannya diberikan kepada fakir miskin, selain itu menurut Ulama Hanafi hukum sah mewakafkan uang akan lebih kuat jika yang menghukumkan boleh mewakafkan uang tersebut adalah seorang Qadhi.

\section{Manfaat Wakaf Uang}

Secara umum, tujuan wakaf adalah untuk kemashalatan manusia, dengan mendekatkan diri kepada Allah SWT, serta memperoleh pahala dari pemanfaatan harta yang diwakafkan yang akan terus mengalir walaupun pewakat sudah meninggal dunia.

Selain itu wakaf memiliki fungsi social, karena sasaran wakaf bukan sekedar untuk fakir miskin tetapi juga untuk kepentingan publik dan masyarakat luas.

Wakaf memiliki sasaran khusus yang spesifik, yaitu $:^{28}$

1. semangat keagamaan

Allah berfirman :"dan carilah wasilah (sarana) untuk menuju kebaikan." (Qs.Al-Maidah : 35). Sasaran wakaf ini berperan sebagai sarana untuk mewujudkan sesuatu yang diniatkan oleh pewakaf, dengan wakaf, pewakaf berniat mendapatkan rido Allah dan pahala yang berkesinambungan selama wakaf tersebut bisa bermanfaat.

2. semangat sosial

Sasaran ini diarahakan pada aktifitas kebajikan, didasarkan pada kesdaran manusia untuk berpartisipasi dalam kegiatan bermasyarakat. Sehingga, wakaf

\footnotetext{
${ }^{26}$ Ibid. Hal. 219

${ }^{27}$ Asep Arsyul Munir, "AGAMA, POLITIK DAN FUNDAMENTALISME," Al-Afkar, Journal For Islamic Studies 1, no. 1 (2018): 149-69.

${ }^{28}$ Sri Nurhayati. Akuntansi Syariah di Indonesia-Wasilah. Jakarta: SalembaEmpat. 2013.h. 338
} 
yang dikeluarkan merupakan bukti kepedulian dalam pembangunan di masyarakat

\section{Simpulan}

Menurut kamus istilah Ekonomi , Keuangan dan Bisnis Syariah wakaf uang adalah wakaf yang berbentuk uang tunai (cash waqf) adapun yang termasuk dalam pengertian uang adalah surat-surat berharga. Wakaf uang hanya boleh disalurkan dan digunakan untuk hal-hal yang dibolehkan secara syar'i, wakaf uang harus dijamin kelestarianya, tidak boleh dijual, dihibahkan maupun di wariskan. ${ }^{29}$

Sesuai dengan keputusan fatwa Majelis Ulama Indonesia (MUI) tertanggal 26 April 2002 diterangkan bahwa yang dimaksud dengan wakaf uang adalah wakaf yang dilakukan seseorang, kelompok orang, lembaga atau badan hukum dala bentuk tunai, Dalam pengertian tersebut, yang dimaksud dengan uang adalah suratsurat berharga.

Adapun dsini peran ulama sangat penting dalam menetapkan hukum wakaf tersebut, karena jika tidak ada ulama yang menetapkan pentingnya hukum wakaf uang tersebut di khawatirkan terjadi banyak perselisihan dikalangan masyarakat umum yang heterogen yang memerlukan penjelasan terkait akan hal tersebut.

Disamping kita dapat mengetahui hukum kseluruhan wakaf uang, wakafuang dapat menjadi satu solusi alternatif dalam membantu mewujudkan kemashalatan dan kesejahteraan dimasyarakat,karena sebagaimana yang sudah kita ketahui bahwa penggunan wakaf uang tersebut sangatlah fleksibel sehingga dapat disesuaikan dengan kebutuhan di masyarakat.

\section{DAFTAR PUSTAKA}

Abdillah, Muhammad bin Ismail Abu, and Muhammad bin Ismail. "Al-Bukhari Al-Jafi, AlJami Al-Shahih Al-Muhtasar.” Jilid I, Beirut: Dar Ibn Katsir, 1987.

Al-Anshary, Abu Yahya Zakariya. "Fath Al-Wahhab.” Juz, n.d.

Al-Khatib, Asy-Syarbaini. "Mughni Al-Muhtaj." Juz II, Mesir: Al-Baby Al-Halaby Wa Auladuhu, 1958.

Alabij, Adijani Al. Perwakafan Tanah Di Indonesia Dalam Teori Dan Praktek. RajaGrafindo Persada, 1989.

Ali, Mohammad Daud. Sistem Ekonomi Islam: Zakat Dan Wakaf. Penerbit Universitas Indonesia, 1988.

Ash-Shan'ani, Imam, and Imam Muhammad bin Ismail al Kahlani. "Subulus Salam Juz III.” Bandung: Dahlan, 1995.

az-Zuhailī, Wahba. Al-Fiqh Al-Islāmī Wa-Adillatuhu: Ǎ̌-Šāmil Lil-Adilla Aš-Šar 'īya Wa-’lȦrā'al-Madhabìya Wa-Ahamm an-Nazarīyāt Al-Fiqhīya Wa-Tahquīq Al-Ahāāīt an-

\footnotetext{
${ }^{29}$ Muhammad Sholahuddin.Kamus Itilah Ekonomi,Keuangan\& Bisnis Syariah. Jakarta : Pt Gramedia Pustaka. 2011.h.189
} 
Nabawīya Wa-Ta Hrīğihā Mulhaqqan Bihi Fahrasa Alifbā'iya Šāmila Lil-Mauḍ̄ 'àt Wa-'l-Masā'il Al-Fiqhīya. Tatimm. Dār al-fikr, 1984.

Haq, Faishal, and H A Saiful Anam. Hukum Wakaf Dan Perwakafan Di Indonesia. Garoeda Buana Indah, 1993.

Lugina, Ugin. "Pengembangan Ekonomi Pondok Pesantren Di Jawa Barat.” Risâlah, Jurnal Pendidikan Dan Studi Islam 4, no. 1 (2017): 53-64.

Munir, Asep Arsyul. "AGAMA, POLITIK DAN FUNDAMENTALISME." Al-Afkar, Journal For Islamic Studies 1, no. 1 (2018): 149-69.

Rofiq, Ahmad. Hukum Islam Di Indonesia. RajaGrafindo Persada, 1995.

Sri Nurhayati, Wasilah. “Akuntansi Syariah Di Indonesia.” Salemba Empat. Jakarta, 2013.

Sunarsa, Sasa. "TAFSIR THEORY; STUDY ON AL-QURAN METHODS AND RECORDS.(TEORI TAFSIR; KAJIAN TENTANG METODE DAN CORAK TAFSIR AL-QURAN).” Al-Afkar, Journal For Islamic Studies 3, no. 1 (2019): 24759.

Syathori, Ahmad. "THE IMPLEMENTATION OF SYARIAH CONCEPT IN MUDHARABAH FUNDING TO MANDIRI SYARIAH BANK IN KCP INDRAMAYU (IMPLEMENTASI PRINSIP SYARIAH TERHADAP PEMBIAYAAN MUDHARABAH PADA BANK SYARIAH MANDIRI KCP INDRAMAYU),” July 10, 2019. https://doi.org/10.5281/ZENODO.3334959.

AL-Mawardi, Al-Hawi Al-Kabir, Juz VII,Beirut: Dar Al-Kutub Ilmiyah, 1994.

M.A. Mannan,Sertifikat Wakaf Tunai, Pancoran-Jaksel: CIBER - PKTTI-UI depok.

Mohammad Daud Ali, Sistem Ekonomi Islam Zakat dan Wakaf, Jakarta: UI Press, 1988.

Muhamad Jawad Nughiyah, Fiqih Lima Mazhab,Jakarta: Lentera, 2005, cet. 13.

Muhammad Ala' Ad Din Ibn Ali, Dar Al Mukhtar Sarhk Tanwir Al Abshar, Juz IV,Beirut: Dar Al Fikr.

Muhammad Sholahuddin.Kamus Itilah Ekonomi,Keuangan\& Bisnis Syariah. Jakarta : Pt Gramedia Pustaka. 2011.

Sayyid Bakri al-Diimyati, I'anah al-Talibin, juz 3, Beirut: Dar al-Fikr.

Sri Nurhayati. Akuntansi Syariah di Indonesia-Wasilah. Jakarta: SalembaEmpat. 2013.

Suparman Usman, Hukum Perwakafan di Indonesia, (Jakarta: Darul Ulum, 1994), Cet. Ke1.

Ulama Indonesia, Keputusan Komisi Fatwa MUI Tentang Wakaf Uang yang dikeluarkan pada tanggal 11 Mei 2002. 2003. 